\title{
Shadow Bureaucracies and the Unilateral Control of International Secretariats: Insights from UN Peacekeeping
}

Citation for published version (APA):

Dijkstra, H. (2015). Shadow Bureaucracies and the Unilateral Control of International Secretariats: Insights from UN Peacekeeping. Review of International Organizations, 10(1), 23-41. https://doi.org/10.1007/s11558-014-9203-7

Document status and date:

Published: 01/03/2015

DOI:

10.1007/s11558-014-9203-7

Document Version:

Accepted author manuscript (Peer reviewed / editorial board version)

Please check the document version of this publication:

- A submitted manuscript is the version of the article upon submission and before peer-review. There can be important differences between the submitted version and the official published version of record.

People interested in the research are advised to contact the author for the final version of the publication, or visit the DOI to the publisher's website.

- The final author version and the galley proof are versions of the publication after peer review.

- The final published version features the final layout of the paper including the volume, issue and page numbers.

Link to publication

\footnotetext{
General rights rights.

- You may freely distribute the URL identifying the publication in the public portal. please follow below link for the End User Agreement:

www.umlib.nl/taverne-license

Take down policy

If you believe that this document breaches copyright please contact us at:

repository@maastrichtuniversity.nl

providing details and we will investigate your claim.
}

Copyright and moral rights for the publications made accessible in the public portal are retained by the authors and/or other copyright owners and it is a condition of accessing publications that users recognise and abide by the legal requirements associated with these

- Users may download and print one copy of any publication from the public portal for the purpose of private study or research.

- You may not further distribute the material or use it for any profit-making activity or commercial gain

If the publication is distributed under the terms of Article $25 f a$ of the Dutch Copyright Act, indicated by the "Taverne" license above, 


\title{
Shadow Bureaucracies and the Unilateral Control of International Secretariats: Insights from UN Peacekeeping
}

\author{
2015 \\ Hylke Dijkstra \\ The final version of this article is forthcoming in: \\ The Review of International Organizations
}

\begin{abstract}
While formal decision power in most international organizations rests with the member states, the member states often delegate the preparation of decisions to international secretariats. To prepare decisions, secretariats gather and analyze information and subsequently provide the member states with an assessment on the alternative courses of action. In this process, secretariats may accumulate an information surplus over the member states. They can use this advantage to suggest options close to their own interests. This article argues that, to counter such agency problem, the member states unilaterally invest in shadow bureaucracies with the aim to reduce informational asymmetries. Shadow bureaucracies are, however, costly. Member states have to weigh agency costs against the costs of domestic administrative capability. Strong states with outlier preferences are most likely to invest in shadow bureaucracies. They have most to gain. The use of shadow bureaucracies not only reduces agency costs. It also allows states more control over policy in international organizations. This article uses insights from peacekeeping in the United Nations to illustrate the argument.
\end{abstract}

\section{KEY WORDS}

control; international organizations; international secretariats; peacekeeping; principal-agent model; shadow bureaucracy 


\section{INTRODUCTION}

Formal decision-making power in most international organizations rests with the member states. The Executive Board of the International Monetary Fund (IMF), consisting of 24 member states representatives, for example, decides on financial assistance. Decisions about the World Heritage List are made by the World Heritage Committee of the United Nations Educational, Scientific and Cultural Organization (UNESCO). It is composed of 21 state representatives. The 15 ambassadors on the United Nations Security Council (UNSC) authorize peacekeeping missions. Indeed in almost every international organization, an intergovernmental board, committee, or council takes the important decisions.

Decision-making requires the member states to assess the anticipated payoffs of alternative courses of action. The IMF, for instance, can insist on conditionality for borrower countries or not. Both options result in different payoffs for the membership. The Executive Board needs to assess these alternatives. A peacekeeping operation can consist of a small or large number of troops. The UNSC will have to make a choice. As many decisions in international organizations are complex, there often exists uncertainty about the payoffs. Member states therefore have an incentive to gather and analyze information about the available options to lower uncertainty about payoffs and take better decisions (Raiffa 1968; George 1980; Feldman and March 1981: 172; Feldman 1989: 4-5). ${ }^{1}$

The preparation of decisions, through information-gathering and analysis, is often formally delegated to international secretariats. Member states expect that secretariats provide better and/or less biased assessments at considerably lower costs than if member states would have to produce such assessments themselves (Abbott and Snidal 1998: 20; Hawkins et al. 2006: 13-15; Dijkstra 2013: 23-27). Delegation avoids that member states have to commit domestic resources. Secretariats specialize and accumulate expertise. They provide also relatively neutral information compared to information originating from interested member states. Delegation therefore lowers information costs. The downside is that it leads to agency costs. By preparing decisions, secretariats gain an informational surplus over the member states. They can exploit this surplus to further their interests by manipulating "the construction of policy alternatives or information about the consequences of different alternatives" (Bendor, Taylor and Van Gaalen 1985: 1042; cf. Martin 2006: 145-147).

The delegation of assessment functions thus presents a classic principal-agent problem. The question is how member states deal with these agency costs. This article argues that member states invest in "shadow" bureaucracies (Lake and McCubbins 2006: 348) to avoid becoming dependent on the recommendations of secretariats. Remarkably, these redundant domestic bureaucracies carry out many of the same functions as secretariats thereby partially undermining the rationale for delegation. Shadow bureaucracies are, however, a costly control mechanism. The extent to which individual member states invest in shadow bureaucracies depends on their resources and agency costs. Shadow bureaucracies allow states unilateral control over secretariats (Urpelainen 2012). States that invest insufficiently in autonomous assessment may lose out.

In the academic literature, shadow bureaucracies have so far been suspiciously absent. Martin (2006: 145-147) recognizes the agency problem in the case of the IMF, but does not discuss how the member states deal with it. Lake and McCubbins (2006: 348), while introducing the term, consider the existence of shadow bureaucracies unlikely because of the high costs. They argue that the member states prefer to rely on decentralized oversight through 'third-party testimony' (ibid.; cf. McCubbins and Schwartz 1984). In the United States (US) Congressional literature scholars have disregarded shadow bureaucracies as well, with the notable exception of Aberbach $(1987,1990)$, who analyzes the "formidable counter organization" (1987: abstract) consisting of an army of congressional staffers overseeing executive agencies. This article puts shadow bureaucracies in the spotlights within the field of international relations.

The article uses insights from United Nations (UN) peacekeeping to illustrate the argument. UN peacekeeping is a most-likely case: the UN Secretariat recommends options to the UNSC and has no agenda-setting or negotiation powers. The formal planning process of peacekeeping missions

1 Feldman et al. present an organizational critique on this economic decision-making model. 
starts with UN Secretariat officials writing a Strategic Assessment. They also go on a fact-finding mission to a country typically far away from the decision-making centre in New York. This planning process provides the UN Secretariat with superior information. Based on an in-house analysis, the Secretary-General sends a report to the UNSC recommending a mission mandate and one or multiple peacekeeping scenarios. One UNSC member then drafts a resolution establishing the operation. This resolution is negotiated with the other members of the Council.

The starting point is to introduce the literature on control mechanisms in international organizations. The article establishes why states invest in shadow bureaucracies. It subsequently discusses one empirical example - the mandate negotiations of the UN Mission in South Sudan (UNMISS) - to illustrate the argument. The article first traces the planning by the UN Secretariat leading to the recommendations of the Secretary-General in May 2011. It then shows how the Council members negotiated their resolution in July 2011. The conclusion discusses how these insights have broader relevance.

\section{CONTROL MECHANISMS AND SHADOW BUREAUCRACIES}

This article argues that member states of international organizations unilaterally invest in so-called shadow bureaucracies to reduce the agency problem resulting from the delegation of functions to international secretariats. This theoretical section first establishes why the combination of goal conflicts and informational asymmetries may result in an agency problem. It subsequently explains how an investment in domestic shadow bureaucracies, thereby reducing the informational surplus of the secretariat, addresses this problem. It conceptualizes shadow bureaucracies and embeds them in the broader literature on oversight mechanisms. This section finally shows that strong member states with outlier preferences are most-likely to invest in shadow bureaucracies.

Principal-agent models are based on two assumptions. ${ }^{2}$ First, principals and agents have different interests. Second, agents have an informational advantage over principals, which they can use to further their interests. A classic example is the patient-physician relationship (Arrow 1963; Evans 1974). Patients want treatment at the lowest possible cost, while physicians have an interest in profit maximization. The superior medical expertise of physicians may lead to supplier-induced demand. Another example concerns the shareholders-management relations (Jensen and Meckling 1976). Shareholders rely on management for daily implementation yet management has better knowledge about the company and an interest in higher salaries.

Goal conflicts and informational asymmetries also play a central role when secretariats prepare assessments and states take decisions. This potentially creates an agency problem. Since the existence of an agency problem is a condition for states to invest in shadow bureaucracies, it is important to first establish that goal conflicts and informational asymmetries exist in relationship to secretariats. Kiewiet and McCubbins (1991: 5) have noted that there is almost always some goal conflict between principals and agents. This is also the case in international organizations, where multiple member states have different interests. Almost by definition, individual member states will thus have some goal conflict with the secretariat. ${ }^{3}$ What is more, secretariats often have their distinct policy preferences. ${ }^{4}$ For example, while the IMF Executive Directors may favor limited conditionality, if borrower countries are political allies, the IMF Staff may push for prudent macroeconomic policy (Martin 2006: 142; Copelovitch 2010; Broome 2014). The WHO Staff is similarly guided by medical and scientific evidence rather than political considerations (Cortell and Peterson 2006: 266-7).

In UN peacekeeping, both conflicting member states preferences and the distinct policy preferences of the UN Secretariat are relevant. First, there exists a North-South divide over whether

2 See Waterman and Meier (1998) for how principal-agent models work if these assumptions are not met.

3 The member states acting as a collective principal (Nielson and Tierney 2003) may, in exceptional cases, have the same preferences as the secretariat, yet this does not prevent individual member states from trying to influence the secretariat (Urpelainen 2012).

4 In addition, secretariats have institutional preferences such as an appetite for larger budgets, more competences and staff (e.g., Vaubel 1986; Pollack 2003; Vaubel, Dreher and Soylu 2007; Niskanen 1971). 
peacekeeping missions should have robust mandates or respect the sovereignty of host countries (Lipson 2010; Benner, Mergenthaler and Rotmann 2011: 16-21). Second, the UNSC is often split when it comes to security questions. This includes the extent to which the UN should invest in a peacekeeping mission in a particular country (Allen and Yuen 2014). Third, UNSC members have different preferences than the member states providing the troops (UN 2014; Cunliffe 2009; Lipson 2010; Breakey and Dekker 2014). Amid these conflicting preferences, the UN Secretariat has its own distinct interests (Allen and Yuen 2014). Ever since the peacekeeping failures in Bosnia, Rwanda and Somalia of the mid-1990s, it aims for "clear, credible and achievable mandates" (UN 2000: 10; UN 2009a). In addition, it tries to promote principles such as impartiality and ownership (UN 2008: 31-43). While there is an appreciation in the Secretariat for robust mandates and the occasional use of force, UN officials are equally worried about overly ambitious mandates, too few resources, and undermining the host government (UN 2014: 24-25). Given the preference heterogeneity of the UN membership and the UN Secretariat's own preferences, the UN Secretariat thus likely has a goal conflict with some of the member states. This is the first pre-condition for a potential agency problem.

In carrying out its functions, the UN Secretariat may accumulate an informational advantage over the member states. To prepare an assessment for the UNSC, UN officials gather information from a variety of sources and go on a fact-finding to the ground (UN 2009b: 11-13). Their data is processed by the more than 600 a-grade in-house experts in the Department of Peacekeeping Operations (DPKO) (Dijkstra 2012; Weinlich 2014). UN officials consider alternatives and make estimations about the required resources. As member states have outsourced this planning function, they no longer carry out these tasks in-house, which potentially results in an informational asymmetry. Importantly, the UN Secretariat does not require superior expertise or exclusive access to information to build up such an informational advantage. Under the assumption of uncertainty and incomplete information, it takes an investment in administrative capacity to gather and process information. Delegation implies that member states divest and secretariats invest in relevant administrative capabilities.

Goal conflicts and informational asymmetries allow agents to exert influence over policy outcomes. Principals therefore have an incentive to consider means to reduce goal conflicts and informational asymmetries (Lupia and McCubbins 1994: 364; Pollack 1997: 108-109; Sridhar and Woods 2013). They do so through a whole range of control mechanisms (Hawkins et al. 2006: 2631). Many of these control mechanisms - such as contract precision, appointment procedures, reporting requirements, sanctions - are formal in nature. They are established by the member states acting as one collective principal (Nielson and Tierney 2003). In addition to such collective oversight, individual member states may invest in unilateral control mechanisms. The aim of unilateral control is to either incentivize the secretariat to pursue policies closer to the interests of the relevant member state (Urpelainen 2012; Panke 2012; Stone 2011) or to reduce the informational advantage of the secretariat vis-à-vis the member state in question. Unilateral control is required when collective oversight proofs insufficient. This happens frequently in international organizations, where multiple principals may have difficulty to agree on effective control mechanisms. ${ }^{5}$

States unilaterally invest in shadow bureaucracies to decrease informational asymmetries. Unilateral controls are, however, costly. Only states with sufficient resources and substantial agency costs will make this investment. It gives those states more control over secretariats and outcomes in international organizations. Shadow bureaucracies come in many forms. They can be defined as any sort of administrative capacity of the principal which gathers, processes and/or verifies information autonomously of the agent in order to exert control. Shadow bureaucracies may consist of a 'front office' and 'back office'. Permanent representations are the front office. They interact with secretariats directly. Part of their daily work is to assess options presented by secretariats and square them with national interests. Diplomats in the permanent representations are supported by a larger back office. They receive instructions and guidance from national ministries, which provide also

5 Some states may have similar preferences as the secretariat. They will thus benefit from secretariat agency and will try to resist collective oversight. 
relevant expertise. National ministries receive information from embassies, intelligence services and other services. Finally, states can make ad hoc capabilities available. Shadow bureaucracies thus compromise the whole domestic machinery.

It is worth to further discuss permanent representations as shadow bureaucracies in order to distinguish shadow activities from other diplomatic functions. Diplomacy, after all, has several functions (Bull 1977: 163-166; Barston 2013: table 1.1). Some permanent representations have mostly a symbolic function: each state needs a presence in New York. There exists, however, strong variation in the size of the diplomatic corps, which cannot be explained by symbolism (see table 1). Permanent representations also serve as transmission belts for national interests. Diplomats clarify national positions, try to persuade other diplomats, and veto policies. Countries with many interests need more diplomats. Yet variation in mission size remains substantial. What sets shadow bureaucracies apart from regular diplomatic functions is the pro-active engagement with information-gathering, processing and verification.

\begin{tabular}{|l|c|l|c|}
\hline Member State & \# Officials & Member State & \# Officials \\
\hline United States & 136 & Nigeria & 24 \\
\hline China & 66 & India & 20 \\
\hline Russian Federation & 66 & Portugal & 15 \\
\hline Germany & 43 & Gabon & 13 \\
\hline United Kingdom & 40 & Colombia & 12 \\
\hline France & 32 & Bosnia and Herzegovina & 9 \\
\hline Brazil & 30 & Lebanon & 9 \\
\hline South Africa & 26 & & \\
\hline $\begin{array}{l}\text { Table 1: Number of officials (third secretaries and higher) working in the Permanent Missions of } \\
\text { UNSC members at the time of the UNMISS planning (March 2011). Source: UN (2011c). }\end{array}$ \\
\hline
\end{tabular}

Permanent representations are the front office of the shadow bureaucracy, as they interact directly with the secretariat. They are, however, informed by a substantial national machinery. To give the example of the United States, the State Department has a dedicated Bureau of International Organization Affairs, formulating and coordinating policy for the UN and its agencies, in addition to its regional and thematic bureaus. The Department of Defense has a policy office for Partnership Strategy and Stability Operations, which deals with UN peacekeeping. The bureaucracies receive a wealth of information, including through the more than 300 US diplomatic missions around the world, which is shared through an interagency process led by the National Security Council in the White House (see further below).

Shadow bureaucracies bear resemblance to the 'police-patrol' oversight mechanism. ${ }^{6}$ Using the case of the US Congress, McCubbins and Schwartz (1984) put forward two ideal-type control mechanisms: police-patrols and fire-alarms. Police-patrols are about "centralized, active and direct" oversight (ibid.: 166) ensuring that executive implementation is in line with legislative goals. Direct surveillance allows for the detection of agency and discourages violations. This ideal-type has relevance in international organizations. Lake and McCubbins (2006: 348) provide the hypothetical example of the World Bank: "[f]or a collection of countries to monitor the World Bank ... one or more of its member states may need to construct its own agency with expertise in international development lending." This would involve "conducting many of the same studies and evaluations that the Bank itself does in order to determine the efficacy of its lending practices" (ibid.).

6 A difference with the model of McCubbins and Schwartz (1984) is that the emphasis in this article is on decisionmaking rather than implementation. Whereas police-patrols deal with 'hidden action', shadow bureaucracies are about uncovering 'hidden information' (Arrow 1985). 
McCubbins and Schwartz (1984) concluded that, in the context of US executive-legislative relations, police-patrols are too costly for Congress. Congress is therefore more likely to rely on indirect, decentralized, ex post fire-alarm oversight. There are, however, reasons why sovereign states, in contrast to Congressmen and women, may prefer to use direct over indirect oversight in international relations. First, it is difficult to change policy in international organizations due to the presence of a large number of principals (Nielson and Tierney 2003; Tsebelis 2002; Dijkstra 2015). Second, contrary to the domestic context, the structures in international relations that allow parties to trigger the alarm are weak. Third, there is a difference between Congress and states acting as principals. It is natural for states to have administrative capacity and to allocate resources in line with their priorities, whereas parliamentarians do not necessarily have a large support staff.

Given the costs of shadow bureaucracies, it is an important question which states invest in shadow bureaucracies. As replicating assessment through parallel structures in the form of shadow bureaucracies is expensive, member states with intensive policy preferences, a significant goal conflict, and substantial resources are most likely to invest in shadow bureaucracies. ${ }^{7}$ Other member states may accept some agency costs or use other control mechanisms instead, while benefitting at the same time from the gains of delegation. Some states may also rely on other states to do the heavy lifting. When a strong state with similar preferences invests in its shadow bureaucracy, states can choose to free-ride. Overall, as a result of the costs, shadow bureaucracies are a form of oversight only available to strong states, which will only use them in case of a significant goal conflict.

Shadow bureaucracies are costly and states unilaterally investing in them are likely to forfeit most, if not all, of their individual benefits of delegation. That being said, it is also important to recognize that investment in shadow bureaucracies is a matter of degree. Thatcher and Stone Sweet (2002: 5) note that potential agency costs equal the sum of delegated powers minus the sum of control. Every dollar not spend on parallel assessment thus potentially leads to agency costs. In reality, states do not have to fully duplicate the assessment to reduce agency costs. First, states and secretariats are likely to have goal conflicts only on certain issues. The UNSC members may have an interest in the mandate, but may be less concerned with the logistical details. Member states can thus be selective. Second, it is normally cheaper to verify assessments than to produce them in the first place. Investments in control mechanisms are therefore likely subject to the law of diminishing returns. Shadow bureaucracies will first target issue areas within an assessment where the potential reduction in agency costs is the largest. Going beyond the low-hanging fruit becomes increasingly more expensive. Under a logarithmic function, a moderate investment in autonomous assessment can substantially reduce agency costs, whereas to fully address agency costs requires a very high investment in control.

Member states often delegate information functions to secretariats to inform the decisionmaking process. Secretariats formally carry out an assessment and report on policy alternatives. While delegation has advantages, it allows secretariats opportunities for agency. To reduce agency costs, states can invest in unilateral control mechanisms, such as shadow bureaucracies, to reduce information asymmetries. These are, however, costly. Member states need to weigh agency costs against the costs of making administrative capabilities available. While individual states may thus forego their benefits from delegation, shadow bureaucracies do not undermine the initial rationale for delegation for the membership as a whole. For states not investing in shadow bureaucracies, the work of secretariats remains beneficial. It avoids that they become dependent on the assessments of other states. They are, as a result, more likely to agree to policy in international organizations and to share part of the burden. This is in everyone's interest. Multiple agents performing similar functions serves a purpose. ${ }^{8}$

7 Panke (2012) finds that within the European Union, the United Kingdom, France, Spain, Finland, Denmark and Germany lobby institutional actors most. These are strong member states with intensive policy preferences. Shadow bureaucracies require more administrative capacity than lobby activities. It is therefore likely that this finding holds as well in the case of shadow bureaucracies.

8 Multiple agents can also be beneficial in a domestic context. The US State Department, for example, can use the UN assessment to not fully rely on the Department of Defense. 


\section{THE MANDATE OF THE UN MISSION IN SOUTH SUDAN}

This section serves as an empirical illustration of the argument. It discusses the planning process of UNMISS. At the time of writing, there were 15 UN operations and UNMISS was only one of them. The advantage of using this particular case is twofold. First, not many member states were familiar with the peacekeeping challenges of South Sudan prior to the planning of the mission. This allowed the Secretariat to accumulate a clear informational advantage. Second, only the US took an interest in South Sudan and invested in a parallel shadow assessment. It is thus relatively straightforward to identify the preferences of the Secretariat and the UNSC members and to see how they impacted on the mandate of the operation. It is an ideal-type case.

The first part of this empirical section traces the assessment and recommendations made by the UN Secretariat concerning the mandate of UNMISS. It shows that following the referendum on the separation of South Sudan from Sudan in January 2011, UN officials went on a six-week factfinding mission. This led to a report of the Secretary-General in May 2011 suggesting peacekeeping options with an emphasis on local ownership and a supportive role for the UN. In parallel, the US sent its own experts to South Sudan and through an internal inter-agency process in Washington developed its own assessment. On this basis, the US presented a draft UNSC resolution in July 2011, which differed from the proposals of the UN Secretariat. The US proposed a proactive and robust role for the UN in the protection of civilians. This resolution was eventually adopted. The stricter, more detailed and more ambitious mandate reduced the autonomy of the UN Secretariat and UNMISS with respect to the implementation of the mission.

\section{Planning of UNMISS by the Secretariat}

The conflicts that took place in the Sudan during the second half of the $20^{\text {th }}$ century are regarded as Africa's longest and worst. The First Sudanese Civil War between the North and the South broke out in 1955 and lasted until 1972. It resulted in a half million casualties. The civil war resumed a decade later following conflicts over the inclusion of Southerns in the Sudanese government located in the capital city of Khartoum in the North. The discovery of considerable oil fields on the boundary between the North and South in the late 1970s made matters worse. The Second Sudanese Civil War lasted from 1983 to 2005 and over two million civilians died as a result of the conflict (UN n.d.[a]).

The Sudanese government in Khartoum and the Sudan People's Liberation Army (SPLA) operating from Juba concluded a Comprehensive Peace Agreement (CPA) in 2005. The idea was two-fold. First, the people of the North and South would try to achieve a unitary state. Second, following an Interim Period of six years, the Southerns would vote in a referendum. They would be able to confirm unity or choose secession (CPA, article 2(5)). To support CPA implementation, the UNSC established the UN Mission in Sudan (UNMIS), a predecessor mission to UNMISS. The Interim Period was full of clashes, however, and many parts of the CPA were not implemented (e.g., Thomas 2009). In the referendum on $9-15$ January $2011,98.83 \%$ of voters chose independence.

The referendum outcome meant that South Sudan would become an independent country on 9 July 2011. Before this could materialize, two problems needed to be addressed. First, the CPA had not been fully implemented. Particularly, the situation in and around the oil-rich city of Abyei, on the border of Sudan and South Sudan remained unresolved. The people of Abyei had been promised a separate referendum on whether to join the North or the South, yet it never took place. Second, separation created new challenges. The border needed to be demarcated, transit fees for oil to be negotiated, and there were issues over citizenship. The Secretariat therefore felt that the existing UNMIS operation needed to continue post-independence for a couple of months. This would also give the new UN mission in South Sudan sufficient time to establish itself. This preference for a 'rollover' from UNMIS to the UNMISS operation was strongly pushed for by Secretariat officials. The Sudanese government, however, rejected this idea and UNMIS was forced to terminate on 9 July 2011 (see further below).

The ongoing challenges in the North and relations between North and South were one thing, 
the internal challenges in South Sudan another. It was clear from the outset that South Sudan would require considerable UN support. While the referendum results had been widely anticipated, the UN could not prejudge the outcome and had to wait with formal planning (interviews national and UN officials). This did not "stop [UN officials] from thinking about the mission" (interview UN official). Brainstorms were held from early 2010 (interview UN official). In November 2010, a small team of local UN officials began writing a Strategic Assessment focusing on South Sudan. This internal process lasted until the end of January (interviews UN officials). The formal planning got underway after the referendum. The UN deployed an Assessment Team from 16 February to 31 March 2011. The Assessment Team had six weeks to gather information and make an assessment of the peacekeeping requirements in South Sudan.

The terms of reference for the Assessment Team were clearly defined by the member states, which reduced the room of maneuver for UN officials. As the North and South did not agree on the outstanding issues, it would focus on "internal peace consolidation challenges" within South Sudan (UN 2011b, paragraph 35). It was tasked to not focus on Sudan or anything that had to do with the border (interview UN official). The Assessment Team worked on two tasks. First, it considered how to support the new government of South Sudan with state-building. Second, it focused on helping the government to strengthen its capacity to "fulfil its sovereign responsibility to protect civilians" (UN 2011a, paragraph 93). Within the framework of these internal challenges, the Assessment Team constructed policy alternatives.

The leadership of the Assessment Team wanted to communicate to the UNSC that a mission in South Sudan would be a difficult undertaking and that member states had to be realistic what could be achieved. ${ }^{9}$ By putting several options forward to address the internal challenges in South Sudan, the UNSC would have a better idea of what to expect with different levels of engagement. Or, as one interviewee stated, "[w]e wanted to have an open discussion." So the Assessment Team went for the full "McDonalds menu" (interview UN official) consisting of three peacekeeping options: "small, medium and large" (ibid.). The first option focused on the protection of UN personnel, installations and critical infrastructure. The mandate was restricted to state-building tasks. It required one battalion and up to eighteen helicopters to create maximum mobility. The second option added an executive role regarding the protection of civilians. Three battalions would be stationed in critical regions, while two others would be used in a more flexible manner. On top of these five battalions, six helicopters and two heavy lift helicopters were required (in total around 7,000 troops). The third option was a static operation with 12,000 troops and a presence throughout South Sudan (interviews national and UN officials).

\begin{tabular}{|c|l|c|c|}
\hline$\#$ & Mandate & Flexibility & Troops \\
\hline 1 & Support government in the protection of civilians & High & 1,000 \\
\hline 2 & $\begin{array}{l}\text { Support government and autonomously protect civilians as a last } \\
\text { resort }\end{array}$ & High & 7,000 \\
\hline 3 & $\begin{array}{l}\text { Support government and autonomously protect civilians as a last } \\
\text { resort }\end{array}$ & Low & 12,000 \\
\hline
\end{tabular}

Table 2. Peacekeeping options of the Assessment Team

The questions put forward by the Assessment Team were: (1) should UNMISS play an executive role in the protection of civilians and have the capability to intervene autonomously from the South Sudanese government, and if so, (2) should UNMISS have a flexible or static presence? The three options did not survive the hierarchy in the Secretariat. The highest military advisor in DPKO did not support the first option, as it raised expectations about UNMISS. Better zero troops and no expectations than one battalion with little capability to protect civilians. The third option was not

9 One of the lessons in the keynote Brahimi report is that the Secretariat should not self-censor and be frank with the Security Council (UN 2000, paragraph 59). 
considered realistic nor ideal. Throughout the process, France and the United Kingdom (UK) had made their budgetary reservations clear. One interviewee stated that "[n]obody wanted to go to the Security Council with a request for 12,000 troops." In addition, "[i]t was also not needed and it was not the message we wanted to send to South Sudan", another interviewee added. Emphasizing the importance of ownership and the supportive role of the UN: five battalions "would allows us to support the local army. The number was deemed correct. It was a fair number" (ibid.). In the end, DPKO leadership decided to put only recommend option two.

The process accumulated in the Special report of the Secretary-General on the Sudan of 17 May 2011 (UN 2011b). In line with Secretariat preferences, the report recommended to the UNSC to adopt a Chapter VI mandate focussing on supporting the new government in peace consolidation, security sector reform, rule of law and the protection of civilians (paragraph 41). ${ }^{10}$ In addition, it suggested that UNMISS should "provide, within capabilities, physical protection to civilians under imminent threat of physical danger, including through the use of force as a last resort when Government security services are unable to provide such security" (paragraph 41(r); cf. paragraph 52(g); emphasis added). For this task, UNMISS would have a Chapter VII mandate. The emphasis was, however, on supporting the government of South Sudan.

The planning of UNMISS was a textbook example of how policy decisions are prepared in international organizations. The UN Secretariat considered several options within the context of a framework set by member states. UN officials went on a fact-finding mission. Their gathered data was processed within the Secretariat. It resulted in a report of the Secretary-General to the UNSC. During the process, the Secretariat accumulated an informational surplus over the member states about the situation in South Sudan. While clearly taking account of the political realities in the UNSC, the UN Secretariat suggested a mandate broadly in line with its own preferences: the local government and not the UN would be responsible for state-building and the protection of civilians. Chapter VI made this very clear. UNMISS would nonetheless have sufficient military resources and a legal mandate to intervene in the worst case scenario. The mandate recommended was thus riskaverse and designed to avoid mission failure.

\section{Negotiating UNMISS in the UNSC}

Following the report of the Secretary-General, the UNSC negotiated its resolution. The US became the so-called 'penholder' given its close relationship with South Sudan. This meant that it drafted the resolution and negotiated it with the other members - first with France and the UK (P3), later with China and Russia (P5) and finally with the elected members (E10). The UNSC adopted its resolution 1996 on 8 July 2011. This was one day before the separation of Sudan and South Sudan. It was around seven weeks after the report of the Secretary-General. The mandate in this Resolution differed from the recommendations of the Secretariat. The resolution was placed completely under Chapter VII and UNMISS received explicit instructions to pro-actively protect civilians under threat. In drafting the resolution, the US was guided by its own autonomous assessment as well as its preferences for robust peacekeeping. Its shadow activities included unilateral fact-finding on the ground and an inter-agency process in Washington.

The US is a strong state within the UNSC and has intensive preferences on peacekeeping as well as the situation in South Sudan. The US pays $28.4 \%$ of the UN peacekeeping budget (UN [n.d.]), equalling nearly 2 billion dollars in 2013, of which 277 million went to UNMISS (Secretary of State 2014: 585). Since the US spends such a significant amount on peacekeeping, and as Congress pays attention, it is unsurprising that it carefully monitors the UN Secretariat and peacekeeping planning. The US has also an interest in South Sudan. It played a key role in the North-South negotiations as part of the 'Sudan Troika' in 2002 together with Norway and the UK. Secretary of State, Colin Powell, for example, co-signed the CPA in 2005. Other US officials were involved as well. Susan Rice, the US ambassador negotiating UNMISS, was a vocal sponsor of

10 Chapter VI provides a legal basis for the "pacific settlement of disputes", while Chapter VII is about "action with respect to threat to the peace" (UN 1945). 
South Sudanese independence. Finally, the US is a major donor of development aid and humanitarian assistance. In 2011, it spent more than 690 million dollars (OECD 2013). This amounts to, no less than, $68 \%$ of total development and humanitarian aid for South Sudan provided by OECD donors. With the US giving so much assistance to South Sudan, it has an overall interest in the country and took a keen interest in the mandate of UNMISS.

The other UNSC members had less intensive preferences on UNMISS. Russia and China had long been important supporters of Sudan. This was significant throughout the CPA negotiations, the referendum and the negotiations on the UN presence with respect to North-South relations. As UNMISS, however, was only concerned with the internal affairs of South Sudan, Russia and China took less of an interest. ${ }^{11}$ The UK has traditionally played a stronger role regarding Sudan, which was under its colonial rule. It was also one of the three members of the Sudan Troika and spends a significant amount on development aid, though far less than the US (OECD 2013). The UK was after the US the UNSC member paying most attention to the UNMISS negotiations. Finally, France had much less interest in the internal situation in South Sudan, instead focusing its efforts on other sub-Saharan countries. As the third largest financer of UN peacekeeping missions, however, it had an interest in keeping the UNMISS budget low. While there were some conflicting preferences in the UNSC on the contents of the UNMISS mandate, the US was by far the most interested actor.

The UNSC resolution was negotiated following the report of the Secretary-General, but it was not fully based on the work of the Secretariat. In fact, the UNSC members carried out their own parallel assessments. The P3, for instance, sent their own experts to South Sudan in the same period as the Assessment Team. These experts wrote their own reports. This was a first instance of shadow activity. Moreover, on 21-24 May 2011, the full UNSC visited Sudan. The P5 ambassadors brought with them their own Sudan experts. The E10 ambassadors took only their personal assistants. Susan Rice was, however, more ambitious. As one interviewee states, she "probably took 100 people." The Council members did not want to rely solely on reports by UN officials.

On their trip, the UNSC ambassadors were also confronted with the harsh reality on the ground. Just before the visit, Sudan intervened in Abyei following an attack by the SPLA against Sudanese troops. The ambassadors issued a press statement condemning the actions of the South and Sudanese government in Khartoum (UNSC 2011). The Sudanese government was not pleased and cancelled all its high-level meetings with the ambassadors. Due to the hostilities, the ambassadors could not visit Abyei. The changing situation on the ground had some important consequences. First of all, it led to the termination of UNMIS. On 27 May 2011, five days after the UNSC statement, Sudan sent a letter to the Secretary-General stating that, with the separation, UNMIS work had come to an end. UNMIS was ordered to leave by 9 July. ${ }^{12}$

The conflict in Abyei made also clear that Sudan and South Sudan could not be trusted (interviews UN officials). As a result, the UN response could have gone in two directions. In line with the recommendations of the Secretariat, a case could be made for increased ownership. The UN should be risk-averse and try to stay out of these issues and make the South Sudanese government responsible. By taking responsibility, with only limited military resources, for such a fragile situation on the ground, the UN would risk peacekeeping failure. As an alternative, there was an argument for a more robust UN mandate. As the local government was not capable of behaving responsibly, UNMISS required the significant military capabilities and a robust mandate. The UN would, after all, need to act in the absence of the local government. UNSC thus needed to make an informed choice.

After the information-gathering on the ground, and before issuing a draft resolution on 30 June (Security Council Report 2011), the US carried out an interagency consultation process in Washington. The interagency process allows all relevant departments input into the draft UNSC

11 As South Sudan's biggest oil importer, China has significantly improved its relations with South Sudan since 2011 and takes an increasingly hands-on approach with regard to security issues. It even has contributed an engineering unit to UNMISS. In 2011, China played however much less of a role in the UN negotatiations.

12 A direct consequence of the intervention was the establishment of the UN Interim Security Force for Abyei (UNISFA). The Ethiopian Prime Minister, Meles Zenawi, decided to send some 4200, mostly Ethiopian, troops to Abyei under UN flag to deter further violence. 
resolution. This includes the Departments of State and Defense, National Security Council, US Agency for International Development, Intelligence Agencies, and the humanitarian organizations. Essentially all these domestic agencies carried out, within their own competences, their parallel assessments. The relevant interagency policy committee took the decision to agree to UNMISS, informed the US Congress, and sent instructions to the US permanent mission, which tabled the UNSC resolution.

It is worth to elaborate on this US interagency process as it constitutes an informal, shadow, planning process as a case in point. One report by the US General Accounting Office (2001) gives a good insight into this process for several earlier UN missions. It notes that for the UN Mission in East Timor, for example, the US Government prepared no less than 19 assessments (ibid.: 11). The interagency policy committee used these assessments to check UN planning against the benchmarks defined by the Presidential Decision Directive 25 outlining US policy towards UN peacekeeping. This is a serious process. For the case of East Timor, for example, the interagency policy committee met nine times. A more senior committee, at the level of undersecretaries, met another three times (ibid.: 12).

Because the US pays a large share of the UN peacekeeping budget, it invests heavily in its shadow bureaucracy. The assessment by the UN Secretariat is considered, in this respect, as only one source of information. A strong statement comes from James Swiger (2004), a Deputy Assistant Secretary in the Bureau of International Organization Affairs: "[ $t]$ hrough the U.S. interagency process, we examine UN reports on peacekeeping, taking them for what they are: recommendations. And the eventual resolutions voted by the Security Council often differ significantly from UN Secretariat recommendations." The US General Accounting Office (2001: 12) similarly notes the secondary nature of UN analysis in earlier missions: "executive branch officials also considered assessments provided by other governments, the U.N. Secretariat, diplomatic envoys and negotiators, regional organizations, and others operating in the areas of concern" (emphasis added).

\begin{tabular}{|l|l|l|c|c|}
\hline Document & Legal basis & Mandate & Flexibility & Troops \\
\hline SG Report & Chapter VI (mostly) & $\begin{array}{l}\text { Support government and autonomously } \\
\text { protect civilians as a last resort }\end{array}$ & High & 7,000 \\
\hline UNSCR & Chapter VII (fully) & $\begin{array}{l}\text { Support government and pro-actively } \\
\text { protect civilians }\end{array}$ & Medium* & $7,000^{* *}$ \\
\hline
\end{tabular}

Table 3: Peacekeeping options by UN Secretariat and UNSC. *During force generation, UNMISS did not receive the number of helicopters it had asked for. ${ }^{*}$ Troops numbers would be reviewed and possibly downsized to 6,000 troops after three or six months.

It is therefore not surprising that the draft resolution on UNMISS, put forwarded by the US, differed in many respects from the peacekeeping options suggested by the UN Secretary-General. While the Secretary-General had recommended a Chapter VI mandate with a few tasks under Chapter VII, the US put the whole resolution under Chapter VII. This meant a much more robust mandate, higher expectations, and less ownership for the South Sudanese government. In the draft resolution, UNMISS was given a pro-active rather than supportive role in the protection of civilians, using "all necessary means" (article 4). To this end, the draft included a lengthy list of tasks UNMISS was supposed to carry out. It included tactical tasks, such as military patrolling and human rights violations reporting, that normally have no place in UNSC resolutions.

The background was the following. The US had been unhappy with the UN Secretariat and some of the troop contributing countries, which had not been carrying out their mandates in accordance with the expectations in Washington (Breakey and Dekker 2014). Not surprisingly troop contributors have been reluctant to risk the lives of their nationals to protect local civilians, even when they are mandated to do so. A UN evaluation indeed notes a "persistent pattern of peacekeeping operations not intervening with force when civilians are under attack" in spite of formal mandates (UN 2014: 1). By giving UNMISS clear instructions, it would have to do things 
that the US considered important. This is a principal-agent dilemma as a case in point. Agents require a wide mandate, as they often know the right course of action. On the other hand, goal conflicts create an incentive for more detailed instructions (Huber and Shipan 2002; Hawkins et al. 2006: 27-28; Allen and Yuen 2014). As one interviewee notes, "Chapter VII does not leave room for interpretation." UNMISS would have to intervene much more forcefully as a result. This created a conflict with the UN Secretariat, which was keen to avoid overly ambitious UN mandates without the necessary resources.

UN officials and many member states were not impressed by the draft resolution. ${ }^{13}$ As one UN interviewee argued, "[i]t was too much, not enough focused." Importantly, another interviewee noted, the US "gave us a challenging mandate but not the resources. We got the minimal size of force." Indeed, while UNMISS was tasked to do more things, the total authorized forced was not increased, against the wishes of the Secretariat. During the negotiations, diplomats from the UK convinced their American counterparts to reduce the number of tasks. The mandate as accepted, nevertheless, remains detailed. UNMISS, for example, is tasked to deter violence "including through proactive deployment and patrols in areas at high risk of conflict" (article 3(b)(v)). It also had to immediately report "gross violations of human rights to the UN Security Council" (article 3(b)(iii)). The mandate was much more activist than recommended by the Secretariat.

Resolution 1996 was adopted on 8 July 2011. It differed from what the Secretariat had recommended. While the report of the Secretary-General had stressed ownership and a central role of the local government in the protection of civilians, the resolution instructed UNMISS to actively engage when civilians are under threat. This mandate was also reinforced by the Chapter VII legal basis. The US thus challenged the assessment of the Secretariat. As a permanent UNSC member, it naturally had the powers to pursue its own preferences, which includes more robust peacekeeping mandates. Yet the US could only credibly do so, as a result of its own information gathering and analysis, and its consultation process in Washington. It had a sufficient informational basis for its decisions. Other Council members were less capable of putting their stamp on UNMISS, due to a lack of domestic shadow bureaucracies, even though they have similar formal powers. This shows the importance of parallel assessment and investment in shadow bureaucracies.

\section{CONCLUSION}

International secretariats often prepare the decisions in international organizations by providing the member states with assessments and sometimes even draft texts. In the process of preparing those decisions, secretariats normally gather and analyze information about the policy alternatives. This potentially puts them in an advantageous position vis-à-vis the member states. Secretariats can use their informational advantage, within the boundaries of what is politically realistic, to manipulate the construction of policy alternatives or misrepresent the likely effects of the alternatives (Bendor, Taylor and Van Gaalen 1985: 1042). Member states therefore have an incentive to decrease informational asymmetries. This article has argued that the member states may unilaterally invest in domestic shadow bureaucracies to lower their dependence on assessments made by secretariats.

The case of peacekeeping planning for the operation in South Sudan has been used as an illustration of this argument. During the first phase, the UN Secretariat gathered and processed information, including through going on a fact-finding mission to South Sudan. It published a report with one policy alternative to inform decision-making in the UNSC. The US, however, essentially ignored the recommendations of the UN Secretariat and acted on its own information when drafting the UNMISS mandate. The US invested in parallel analysis given its significant interests in South Sudan and peacekeeping. Other UNSC members were less interested and did not engage in extensive parallel planning. This allowed the US considerable unilateral control. The case of UN peacekeeping planning in South Sudan thus illustrates the argument. Shadow bureaucracies may exist, however, not only in the field of peacekeeping and the US is probably not the only member

13 The United States did not even informally discuss the draft resolution with the UN officials, who had planned the mission and would have the responsibility to implement the mission (interviews UN officials). 
state investing in shadow bureaucracies. Many member states in many international organizations can use shadow bureaucracies across a whole range of policy areas. Member states' investments in parallel assessments allow for greater control.

It is useful, at this point, to give some additional examples. The use of chemical weapons in Syria in 2013 provides an interesting case. This instance differs from UNMISS in that many more UN member states had a clear interest. Experts from the UN, Organisation for the Prohibition of Chemical Weapons and World Health Organization were formally tasked to carry out an investigation and report back to the UNSC to inform decision-making. This could have potentially given them agency with respect to their final report. The formal tasking did not prevent the UNSC members, however, to carry out their own parallel assessments (see Day 2013; White House 2013; French Government 2013). Indeed, the case of chemical weapons was so contested in the UNSC that at least four of the five permanent members did not want to be dependent on the information of the formally appointed experts.

It is also worth looking at an example from a different policy field: the Greek bailout. The European Union and IMF send policy experts to Athens on a regular basis for fact-finding. This socalled Troika assesses the progress Greece has made. Based on its report, the member states decide whether to wire new installments to Athens. Delegation has considerable benefits including blameshifting (Fiorina 1982: 47-48; Charlemagne 2014). The member states have, of course, their ways of controlling the Troika. German unilateral control is particularly interesting. Germany pays the largest share and has an interest in strong conditionality. It wants to keep the Troika on a tight rein. To do so Germany organizes, among others, its own bilateral missions to Greece in addition to its regular diplomatic reporting by its local embassy. Germany therefore has an accurate understanding of the economic challenges in Greece.

There are thus potentially many examples of shadow bureaucracies at work. The objective of this article has been to point at their theoretical importance and to suggest to include them in the analysis of control in international secretariats. Academically, shadow bureaucracies remain in the shadows. While some scholars have recognized the underlying agency problem (Martin 2006: 145147), and others have considered the investment is shadow bureaucracies as a possible control strategy (Lake and McCubbins 2006: 348), insufficient attention has been paid to how states, through parallel channels, keep control over international secretariats.

While this article has shown that states use shadow bureaucracies to control secretariats and international organizations, it has found little evidence that the US tried to unilaterally influence the UN Secretariat. The US was certainly informally involved at early stages of the planning, had sufficient privileged access as well as nationals in key planning positions, yet it preferred to act through the UNSC rather than the Secretariat. Given that it is typically assumed that strong states hold more influence over secretariats than weak states (Stone 2011; Urpelainen 2012), this presents a new puzzle. Perhaps the US anticipated few difficulties in the UNSC or perhaps convincing UN officials was deemed too costly or tiresome. This difference between unilateral influence and unilateral control requires additional research.

\section{ACKNOWLEDGEMENTS}

This article was previously presented at workshops in Oxford and Maastricht in December 2013, and at the ECPR Joint Sessions of Workshops in Salamanca in April 2014. The author wishes to thank Michael W. Bauer, Derek Beach, Mareike Kleine, Duncan Snidal, all other participants at these workshops as well as the two anonymous reviewers and editor for their helpful comments.

The research leading to these results has received funding from the People Programme (Marie Curie Actions) of the European Union's Seventh Framework Programme (FP7/2007-2013) under REA grant agreement $\mathrm{n}^{\circ}$ [298081]. 


\section{REFERENCES}

Abbott, K. \& Snidal, D. (1998). Why states act through formal international organizations. Journal of conflict resolution, 42(1), 3-32.

Aberbach, J. (1987). The Congressional Committee Intelligence System: Information, Oversight, and Change. Congress and The Presidency, 14(1), 51-76.

Aberbach, J. (1990). Keeping a Watchful Eye: The Politics of Congressional Oversight. Washington, DC: The Brookings Institution.

Allen, S. \& Yuen, A. (2014). The Politics of Peacekeeping: UN Security Council Oversight Across Peacekeeping Missions. International Studies Quarterly, doi:10.1111/isqu.12086.

Arrow, K. (1963). Uncertainty and the welfare economics of medical care. The American Economic Review, 53(5), 941-973.

Arrow, K. (1985). The Economics of Agency. In J. Pratt \& R. Zechhauser (Eds), Principals and Agents: The Structure of Business. Cambridge: Harvard University Press.

Barston, R. (2013) Modern Diplomacy, $4^{\text {th }}$ edition. Harlow: Pearson Education.

Bendor, J., Taylor, S. \& Van Gaalen, R. (1985). Bureaucratic Expertise versus Legislative Authority: A Model of Deception and Monitoring in Budgeting. American Political Science Review, 79(4), 1041-1060.

Benner, T., Mergenthaler, S. \& Rotmann, Ph. (2011). The New World of UN Peace Operations: Learning to Build Peace?. Oxford: Oxford University Press.

Breakley, H. \& Dekker, S. (2014). Weak Links in the Chain of Authority: The Challenges of Intervention Decisions to Protect Civilians. International Peacekeeping, doi:10.1080/13533312.2014.928572.

Broome, A. (2014). Back to Basics: The Great Recession and the Narrowing of IMF Policy Advice. Governance, doi:10.1111/gove.12098.

Bull, H. (1977). The Anarchical Society: a study of order in world politics. London: Macmillan.

Charlemagne (2014). The euro's hellhound. The Economist, 1 February.

http://www.economist.com/news/europe/21595432-it-time-reform-troika-handles-euro-zone-bailouts-euros-hellhound. Accessed 10 March 2014.

Comprehensive Peace Agreement (9 January 2005).

http://peacemaker.un.org/sites/peacemaker.un.org/files/SD 060000 The $\% 20$ Comprehensive \%20Peace\%20Agreement.pdf. Accessed 27 May 2013.

Copelovitch, M. (2010). Master or servant? Common agency and the political economy of IMF lending. International Studies Quarterly, 54(1), 49-77.

Cunliffe, Ph. (2009). The politics of global governance in UN peacekeeping. International Peacekeeping, 16(3). 323-336. 
Day, J. (2013). Letter From the Chairman of the Joint Intelligence Committee to the Prime Minister on Syria: Reported Chemical Weapons Use. London: White Hall, Cabinet Office, 29 August.

Dijkstra, H. (2012). Efficiency versus Sovereignty: Delegation to the UN Secretariat in Peacekeeping. International Peacekeeping, 19(5), 581-596.

Dijkstra, H. (2013). Policy-Making in EU Security and Defense: An Institutional Perspective. Basingstoke: Palgrave Macmillan.

Dijkstra, H. (2015). Functionalism, Multiple Principals and the Reform of the NATO Secretariat after the Cold War. Cooperation and Conflict. doi:10.1177/0010836714532919.

Evans, R. (1974). Supplier-induced demand: some empirical evidence and implications. In M. Perlman (Ed.), The Economics of Health and Medical Care. London: Macmillan, pp. 162-173.

Feldman, M. (1989). Order Without Design: Information Production and Policy Making. Stanford: Stanford University Press.

Feldman, M. \& March, J. (1981). Information in Organizations as Signal and Symbol. Administrative Science Quarterly, 26(2), 171-186.

Fiorina, M. (1982). Legislative choice of regulatory forms: Legal process or administrative process?. Public Choice, 39(1), 33-66.

French Government (2013). Programme chimique syrien: Cas d'emploi passés d'agents chimiques par le régime: Attaque chimique conduite par le régime le 21 août 2013, 2 September.

http://www.gouvernement.fr/sites/default/files/fichiers joints/syrie_synthese nationale de renseign ement declassifie 02 09 2013.pdf. Accessed 28 January 2014.

George, A. (1980). Presidential decisionmaking in foreign policy: the effective use of information and advice. Boulder: Westview Press.

Hawkins, D. et al. (eds) (2006). Delegation and Agency in International Organizations. Cambridge: Cambridge University Press.

Huber, J. \& Shipan, C. (2002). Deliberate Discretion? The Institutional Foundations of Bureaucratic Autonomy. Cambridge: Cambridge University Press.

Jensen, M. \& Meckling, W. (1976). Theory of the firm: Managerial behavior, agency costs and ownership structure. Journal of financial economics, 3(4), 305-360.

Kiewiet, D. \& McCubbins, M. (1991). The Logic of Delegation: Congressional Parties and the Appropriations Process. Chicago: University of Chicago Press.

Lake, D. \& McCubbins, M. (2006). The logic of delegation to international organizations. In D. Hawkins et al. (Eds), Delegation and Agency in International Organizations. Cambridge: Cambridge University Press, 341-68.

Lipson, M. (2010). Performance under ambiguity: international organization performance in UN peacekeeping. The Review of International Organizations, 5(3), 249-284.

Lupia, A. \& McCubbins, M. (1994). Who controls? Information and the structure of legislative 
decision making. Legislative Studies Quarterly, 19(3), 361-384.

Martin, L. (2006). Distribution, information, and delegation to international organizations: the case of IMF conditionality. In D. Hawkins et al. (eds), Delegation and Agency in International Organizations. Cambridge: Cambridge University Press, 140-164

McCubbins, M. \& Schwartz, T. (1984). Congressional oversight overlooked: Police patrols versus fire alarms. American Journal of Political Science, 28(1), 165-179.

Nielson, D. \& Tierney, M. (2003). Delegation to international organizations: Agency theory and World Bank environmental reform. International Organization, 57(2), 241-276.

Niskanen, W. (1971). Bureaucracy and Representative Government. New Brunswick: Transaction Publishers.

OECD (2013). South Sudan - Disbursements of bilateral ODA by donor and sector (2011). Aid statistics by recipient and sector.

http://www.oecd.org/dac/stats/documentupload/DataDonorRecipientSectorChart.zip. Accessed on 18 November 2013.

Panke, D. (2012). Lobbying Institutional Key Players: How States Seek to Influence the European Commission, the Council Presidency and the European Parliament. Journal of Common Market

Studies, 50(1), 129-150.

Pollack, M. (1997). Delegation, agency, and agenda setting in the European Community. International Organization, 51(1), 99-134.

Pollack, M. (2003). The engines of European integration: delegation, agency, and agenda setting in the EU. Oxford: Oxford University Press.

Raiffa, H. (1968). Decision Analysis: Introductory Lectures on Choices under Uncertainty. Reading: Addison-Wesley.

Secretary of State (2014). Congressional Budget Justification: Appendix 1, Fiscal Year 2015. http://www.state.gov/documents/organization/223495.pdf. Accessed 17 July 2014.

Security Council Report (2011). Resolution on a UN mission in South Sudan. 6 July. http://www.whatsinblue.org/2011/07/rsolution-on-a-new-mission-in-sudan.php. Accessed 26 November 2013.

Sridhar, D. \& Woods, N. (2013). Trojan Multilateralism: Global Cooperation in Health. Global Policy, 4(4), 325-335.

Stone, R. (2011). Controlling institutions: International organizations and the global economy. Cambridge: Cambridge University Press.

Swigert, J. (2004). Challenges of Peacekeeping in Africa. Statement before the Africa Subcommittee of the House International Relations Committee, 8 October. http://20012009.state.gov/p/io/rls/rm/2004/39154.htm. Accessed 27 August 2014.

Thatcher, M. \& Stone Sweet, A. (2002). Theory and Practice of Delegation to Non-Majoritarian Institutions. West European Politics, 25(1), 1-22. 
Thomas, E. (2009). Against the Gathering Storm Securing Sudan's Comprehensive Peace Agreement. London: Chatham House.

Tsebelis, G. (2002). Veto players: How political institutions work. Princeton: Princeton University Press.

UN (n.d.[a]). UNMIS Background. http://www.un.org/en/peacekeeping/missions/unmis/background.shtml. Accessed 28 May 2013.

UN (n.d.[b]). Financing Peacekeeping. http://www.un.org/en/peacekeeping/operations/financing.shtml. Accessed 17 July 2014.

UN (1945). Charter of the United Nations. http://treaties.un.org/doc/Publication/CTC/uncharter.pdf. Accessed 18 November 2013.

UN (2000). Report of the Panel on United Nations Peace Operations [Brahimi Report]. A/55/305 S/2000/809, 21 August.

UN (2008). United Nations Peacekeeping Operations: Principles and Guidelines [Capstone Doctrine]. New York: Department of Peacekeeping Operations and Department of Field Support, 18 January.

UN (2009a). A New Partnership Agenda: Charting A New Horizon for UN Peacekeeping. New York: Department of Peacekeeping Operations and Department of Field Support, July.

UN (2009b). IMPP Guidelines: Role of the Headquarters. Internal document approved by the UN Secretary-General, May.

UN (2011a). Report of the Secretary-General on the Sudan. S/2011/239, 14 April.

UN (2011b). Special report of the Secretary-General on the Sudan. S/2011/314, 17 May.

UN (2011c). Permanent Missions to the United Nations. ST/SG/SER.A/301, New York: United Nations, Executive Office of the Secretary-General, Protocol and Liaison Service, March.

UN (2014). Report of the Office of Internal Oversight Services on Evaluation of the implementation and results of protection of civilians mandates in United Nations peacekeeping operations. A/68/787, 7 March.

UNSC (2011). Press Statement by Mr Gérard Araud, President of the Security Council. 22 May. http://www.franceonu.org/france-at-the-united-nations/press-room/speaking-to-the-media/remarksto-the-press/article/22-may-2011-abyei-sudan-press. Accessed 4 July 2013.

Urpelainen, J. (2012). Unilateral Influence on International Bureaucrats: An International Delegation Problem. Journal of Conflict Resolution, 56(4), 704-735.

US General Accounting Office (2001). U.N. Peacekeeping: Executive Branch Consultations With Congress Did Not Fully Meet Expectations in 1999-2000. Report to Congressional Requesters. GAO-01-917, September.

Vaubel, R. (1986). A public choice approach to international organization. Public Choice, 51(1), 39- 
57.

Vaubel, R., Dreher, A. \& Soylu, U. (2007). Staff growth in international organizations: A principalagent problem? An empirical analysis. Public Choice, 133(3-4), 275-295.

Waterman, R. \& Meier, K. (1998). Principal-agent models: an expansion?. Journal of public administration research and theory, 8(2), 173-202.

Weinlich, S. (2014). The UN Secretariat's Influence on the Evolution of Peacekeeping. Basingstoke: Palgrave Macmillan.

White House (2013). Government Assessment of the Syrian Government's Use of Chemical Weapons on August 21, 2013. Washington, DC: White House, Office of the Press Secretary, 30 August. http://www.whitehouse.gov/the-press-office/2013/08/30/government-assessment-syriangovernment-s-use-chemical-weapons-august-21. Accessed 28 January 2014. 